\title{
SOCIAL WORK WITH CHILDREN AND FAMILIES
}

\section{Maureen O'Loughlin i Steve O'Loughlin, (2012). Third Edition. SAGE.}

UDK:364.044:364.65-053.2

Recenzija, prikaz

Socijalni rad s djecom i obiteljima tema je koja je u svakom slučaju nezaobilazna kada je riječ o studentima socijalnog rada. Kroz mnoge obvezne i izborne kolegije tijekom studija, studenti se upoznaju sa socijalnim radom s djecom i obiteljima. Autori O'Loughlin u svojoj knjizi vode čitatelja kroz zakonodavstvo, politiku i pravo koje okružuje socijalni rad s djecom i obiteljima, dajući pritom čvrste temelje za kritičko promišljanje. Maureen O'Loughlin jest nezavisna savjetovateljica socijalnog rada koja ima mnogo iskustva u radu s djecom i obiteljima kao socijalna radnica te kao skrbnik u većem broju sudskih slučajeva. Steve O'Loughlin također radi kao nezavisni savjetovatelj socijalnog rada. Trenutno radi kao asistent/instruktor za studente te je također iskusan u slučajevima posvojenja i udomiteljstva te radi nezavisne procjene za iste. Također radi kao zastupnik za njegovatelje i mlade.

Knjiga Social Work with Children and Families, treće izdanje, namijenjena je prvenstveno studentima i stručnjacima iz područja socijalnog rada. Knjiga je podijeljena na 7 poglavlja:

Vrijednosti i etika u socijalnom radu s djecom i obiteljima - u kojem autori obrazlažu brojne etičke dileme koje se mogu javiti prilikom rada te daju savjete kako iste riješiti i postupiti profesionalno kod javljanja istih

Zakonodavni $i$ politički kontekst socijalnog rada s djecom i obiteljima - u kojem iznose povijesni i politički kontekst razvoja socijalnog rada s djecom i obiteljima.

Podrška obiteljima u socijalnom radu s djecom i obiteljima - ideje oko suportivnog i preventivnog rada te stavljanje naglaska na individualnost svakog djeteta i svake obitelji pa tako i na jedinstven pristup u radu s njima.

Efektivni rad s djecom i obiteljima u svrhu zaštite djece - znanja i vještine koje socijalni radnik treba posjedovati kako bi uspješno radio na problemima zlostavljanja djece, posebice stavljajući naglasak da kod svake prevencije/intervencije dobrobit djeteta treba biti na prvom mjestu. 
Direktni rad s djecom i mladima - opisuju planiranje procesa i sam proces direktnog rada s djecom i mladima kroz diskusiju te brojne praktične načine pristupanja i razumijevanja djece i mladih.

Socijalni rads djecom s poteškoćama u razvoju i njihovim obiteljima - autori navode neke poteškoće koje se mogu javiti u radu s djecom s poteškoćama u razvoju i njihovim obiteljima te kroz različite praktične primjere rješavanja tih poteškoća naglašavaju da bismo kao socijalni radnici fokus trebali staviti na rad s djecom, a ne na rad s njihovim poteškoćama s kojima žive.

Izvanobiteljska skrb za djecu - posljednje poglavlje je posvećeno udomiteljstvu, posvojenju te institucionalnim oblicima skrbi za djecu, a autori koriste materijale raznih slučajeva kako bi naglasili vještine koje socijalni radnici trebaju posjedovati, posebice kod procjene pojedinačnog slučaja.

Autori odlično povezuju praksu sa zakonodavstvom te ističu relevantne nalaze istraživanja kojima potkrijepljuju svoje navode. Knjiga je puna primjera i praktičnih savjeta koji su realistično povezani sa zadacima modernog socijalnog rada što pridonosi preglednosti same knjige, te što je još bitnije, olakšava usvajanje novih znanja. Na kraju svakog poglavlja napisan je i kratak sažetak kako bi studenti mogli ponoviti u kratkim crtama ono što su pročitali te utvrditi gradivo još jednom.

Kritika koja se može uputiti knjizi jest ta da govoreći o radu s djecom i obiteljima, ne govori o tehnikama rada i pristupu rada sa specifičnim skupinama roditelja, primjerice ovisnicima, roditeljima s invaliditetom i slično.

Kako su autori knjige iz Velike Britanije, knjiga je i pisana u kontekstu britanskog zakonodavsta i njihovih politika, no smatram da je to samo još jedna pozitivna stvar za studente socijalnog rada iz Republike Hrvatske, budući da mogu dobiti uvid kako socijalni rad s djecom i obiteljima funkcionira u Velikoj Britaniji. Također, knjiga je pisana jednostavnim rječnikom te se ne koriste komplicirane engleske riječi. Stoga knjiga može poslužiti kao odličan uvod u socijalni rad s djecom i obiteljima. 